\title{
Patiëntenvoorlichting
}

\section{PV 41. Simpele botcyste}

Een simpele botcyste is een door onbekende oorzaak ontstane, soms enkele centimeters grote, holte in het bot. Deze holtevorming kan zich in bijvoorbeeld de bovenbenen voordoen, maar ook in het kaakbot. Het betreft vrijwel altijd de onderkaak.

De simpele botcyste komt vrijwel uitsluitend tussen het 10e-25e jaar voor en veroorzaakt zelden klachten. De cyste wordt meestal bij toeval ontdekt op een röntgenfoto van de kaak die bijvoorbeeld is gemaakt bij de voorbereiding van een orthodontische behandeling. De diagnose kan niet met zekerheid op grond van alleen de röntgenfoto worden gesteld en vereist een kleine operatieve, meestal onder plaatselijke verdoving uitgevoerde, inspectie. Wanneer daarbij een lege holte in het bot wordt aangetroffen, staat de diagnose vast. Het is niet nodig om de botholte met enig materiaal op te vullen. De tanden in het betreffende gebied blijven onaangetast Vrijwel altijd treedt na inspectie van de botholte spontaan herstel op. Dit herstel kan worden geverifieerd met behulp van een röntgenfoto. Meestal wordt een dergelijke controlefoto een jaar na de inspectie gemaakt. In het zeldzame geval dat de holte geen tendens tot genezing toont, wordt soms een hernieuwde inspectie uitgevoerd.

\section{Wat kunt u zelf doen?}

Hoewel op grond van de röntgenfoto gedacht zou kunnen worden aan een door de holte veroorzaakte verzwakking van het kaakbot, blijkt in de praktijk eigenlijk nooit een breuk op te treden en is er bijvoorbeeld geen reden om na de behandeling een aangepast, zacht, dieet te volgen
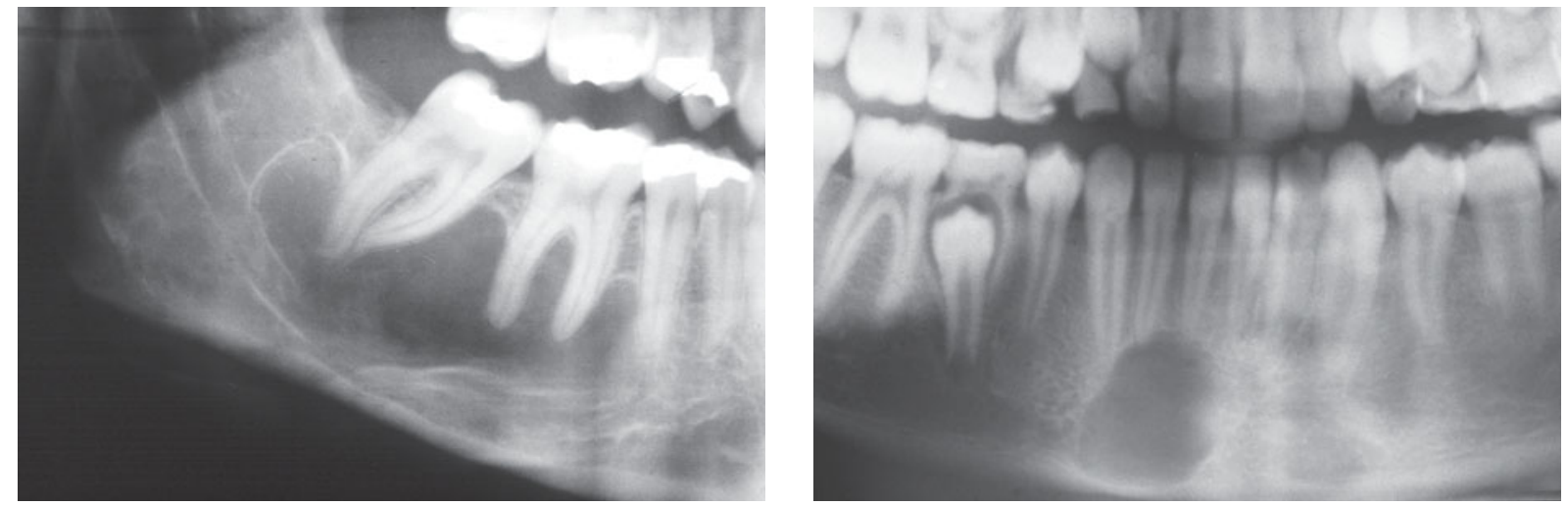